\section{Lærebok om behandling av hud med og uten sår}

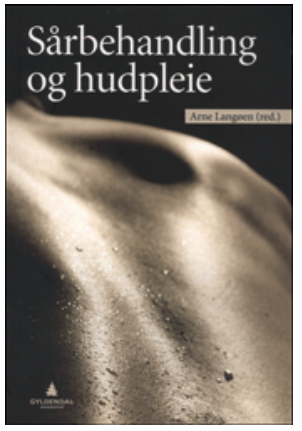

Arne Langøen

Sårbehandling og hudpleie

317 s, tab, ill. 4. utg. Oslo: Gyldendal

akademisk, 2012 Pris NOK 449

ISBN 978-82-05-41518-18

Boken er skrevet som en lærebok innen sårbehandling og hudpleie. Den har innledningsvis et kapittel om hudens funksjon og oppbygging, deretter er antall sider fordelt omtrent likt mellom temaene kroniske sår og hudpleie. Den er lettskrevet i muntlig stil, med forfatterens kommentarer innimellom. Formatet er A5, og illustrasjonene består av fotografier, tabeller, flytskjemaer og summariske oversikter.

Medisinsk håndtering av kroniske sår har tradisjonelt vært ekspektant hva gjelder både diagnostikk og behandling. De siste ti årene har kulturen endret seg til en betydelig mer aktiv holdning. Ny kunnskap er kommet om sårvæskens innhold av aktive inflammatoriske substanser, som gir protrahert forløp med bakteriekolonisering, produksjon av biofilm og residiverende infeksjoner. Slike sår skal nå behandles med revisjon av sårflate og tilpasset hyppighet på bandasjeskift til sårets karakter.

I det første kapitlet om kroniske sår får leseren en bred og oppdatert oversikt over patofysiologiske mekanismer som man i dag mener er av betydning for protrahert sårtilheling. Videre er det en oversikt over moderne prinsipper for sårbehandling med indikasjon og protokoll for fluelarver, vakuumbehandling og delhudstransplantasjon. Oversikten over type bandasjemateriell på markedet er god, og i tabellform får man råd om hvilke man bør velge til ulike sår, i tillegg til forskjellig type kompresjonsbehandling. I det neste kapitlet tar forfatteren for seg diagnostikk og betydningen av kirurgisk intervensjon på arterie- og venesiden og forebygging og behandling av diabetessår og trykksår. For å ivareta sårbehandling i tråd med moderne behandlingsprinsipper kreves god logistikk og godt samarbeid mellom hjemmesykepleie, fastlege og spesialisthelsetjeneste. Avslutningsvis er det en oversikt over ulike modeller for hvordan sårarbeidet er organisert i Norge.

Det andre temaet, hudpleie, er fordelt på tre kapitler, hvorav det første inneholder en detaljert oversikt, laget av farmasøyt, om indifferente hudprodukters fremstilling, innhold og funksjon. De øvrige kapitlene handler om ivaretakelse av normal hud i ulike aldre og stell av hud som utsettes for påkjenninger som uttørring, fuktighet, soling og kløe. Kapitlene inneholder også en del praktiske tips.

Dette er en kjærkommen og oppdatert bok innen sårbehandling. Innholdsmessig er den relativt omfattende sett i forhold til sidetallet, noe som kan forklare at den fremstår som litt ujevn. Temaet sårbehandling er på et høyt medisinskfaglig nivå, men jeg savner en omtale av behovet for biopsitaking under utredningskapitlet. Hudpleiedelen fremstår som noe mindre gjennomarbeidet, og stedvis er det noen avvik fra generelle dermatologiske behandlingsprinsipper og terminologi.

Boken kan absolutt anbefales og bør kunne leses av alle grupper den er tiltenkt: sykepleiere, studenter, helsefagarbeidere og farmasøytisk personell, i tillegg til leger med interesse for sårbehandling.

\section{Tone Kristin Bergersen}

Hudavdelingen

Oslo universitetssykehus, Rikshospitalet

Oppgitte interessekonflikter: Anmelderen er styremedlem i Norsk interesseforening for sårheling (NIFS), og Arne Langøen er leder av NIFS.

\section{Råd og vink om digital støtte av undervisning}

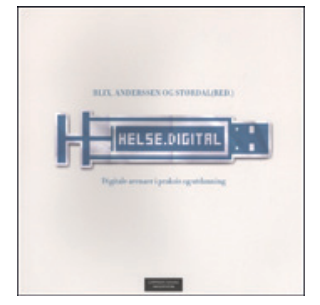

Siw Blix, Norman Anderssen,

Tove Størdal, red.

helse.digital

Digital arenaer i praksis og utdanning. $300 \mathrm{~s}$

tab, ill. Oslo: Cappelen Damm Akademisk,

2012. Pris NOK 398

ISBN 978-82-02-35020-8

Dagens studenter er vant til teknologi og har forventninger til at universiteter og høyskoler skal ta i bruk IKT i undervisningen. Flertallet av underviserne er ikke like vant med IKT, og mange kan kvie seg for å gå inn i dette. Denne boken henvender seg til undervisere som har tatt i bruk eller ønsker å ta i bruk elektroniske hjelpemidler $i$ arbeidet med studentene. Forfatterne tar utgangspunkt $i$ undervisning av sykepleiere, men erfaringene som forfatterne har gjort, har like stor relevans for øvrige profesjoner. Hovedforfatterne er intensivsykepleier med master i helsefag, psykolog og professor i sosialpsykologi og sykepleier og jordmor med master i helsefag.

Forfatterne tar for seg bruk av simuleringsprogramvare, elektronisk organisering av undervisningen («Learning Management Systems»), utvikling av virtuelle fagnett, støtte for studenter med leseog skrivevansker og gjennomføring av fjernundervisning og eksaminering via videokonferanse. I tillegg blir helsepersonells behov for IKT-kompetanse berørt, og moderne studenters forhold til digitale medier blir diskutert. Boken inneholder også erfaringer fra brukerdrevet innovasjon og produktutvikling hvor læresteder og næringsliv samarbeider. Sistnevnte kapitler skiller seg tematisk ut fra resten av innholdet, men de har interessante sider.

Dette er en engasjerende og velskrevet bok, selv om innholdet veksler mellom det mer dyptgående og det helt summariske. Forfatterne har lyktes best der de systematiserer egne erfaringer og presenterer dem med kommentarer. Erfaringene er bygd opp over 20 år, ved prøving og feiling gjennom flere generasjoner teknologi. Dette er generiske momenter, de gir ingen instruksjoner for navngitte IKT-systemer, og det er nyttig lesning for alle som har tenkt å bruke IKT direkte eller indirekte i sin undervisning. Øvrige deler fungerer mer som innspill i en debatt om IKT, og bør leses som sådan. Jeg vil anbefale boken for den som er nysgjerrig på emnet, og som underviser studenter selv.

\section{Hallvard Lærum \\ IT-avdelingen \\ Oslo universitetssykehus, Rikshospitalet}

